these all but seventeien are proved by their remains to have inhabited Somerset, viz:-man, the care-lion, the cave-panther, the wild cat, the cave-hyæena, the wolf, the fox, the glutton, the marten cat, the otter, the badger, the cave-bear, two species of bat, the bison, the urus, the reindeer, the red deer, the roedeer, the musk-sheep, the Irish elk, the wild boar, the horse, two species of rhinoceros, two epecies of elephant, the water-rat, the hare, the rabbit, the marmot, and the extinct hippopotamus.

\title{
OORERSPOITDEITCE.
}

\section{ON THE DISCOVERY OF A BED OF DEVONIAN CORALS AT WITHYCOMBE, WEST SOMERSET.}

\section{To the Editor of the Grological Magazine.}

Srn,-There is a band of Limestone, mentioned by Sir H. de la Beche, in his Geological Report on Cornwall, Devon, and West Somerset, which is traceable at intervals from Ilfracombe to Withycombe, the intervening localities being Combe Martin, Simonsbath, Cutcombe, Duxborough, and Treborough, and to quote his words, " if we be right in referring the Limestone of the Quantocks to the same band, it is carried round by Doddington, Asholt, and Cothelstone Park, the connection being concealed by the Red Sandstone series, the Lias, and the Sea."

The existence of Coral-beds in the portion of this Limestone band exposed in the Quantocks has been ascertained by Mr. J. D. Pring, of Taunton, and the only genera and species that $I$ at present know to have been found in them-though doubtless there are many others-are the following: viz., Alveolites suborbicularis, Favosites polymorpha (cervicornis, M. Edwards), Favosites reticulata, Heliophyllum Halli (\%), Endophyllum abditum, and an Acervularia. Of these species, specimens, presented by Mr. Pring, are to be seen in the Maseum, at Taunton, and in the Collection of the Geological Society, at Somerset House.

In the spring of $1860 \mathrm{I}$ was so fortunate as to discover that a Coral-bed existed in the Withycombe portion of this Limestone band, partially exposed in the fields above Sandhill Farm. I was very much interested in the discovery, as I had never expected to meet with Fossils in the Devonian Rocks of the neighbourhood, and from this time, till Iileft the district in 1863, I made occasional visits to the spot, and searched every part of the bed, which is exposed over a very small area, repeatedly and thoroughly, and succeeded in collecting a great number of specimens. These I have named chiefly by means of polished sections, and the following is_a list of their genera and species. 


\section{List of Corals from Withycombe.}

ve., very common; c., common; r., rare.

1. Fenestella antiqua, c.

2. Stromatopora concentrica, $\mathrm{c}$.

3. Favosites cervicornis, ve.

4. Favosites reticulata, vc.

5. Alveolites suborbicularis, $\mathrm{c}$.

6. Alveolites (species?), $\mathrm{c}$.

7. Syringopora (undescribed), r.
8. Amplexus (tortuosus ?), $\mathrm{r}$.

9. Cyathophyllum (Damnomiense ?), r.

10. Cyathophyllum Boloniense, ve.

11. Cyathophyllum crespitosum, vc.

12. Heliophyllum Halli, c.

13. Endophyllum abditum, $\mathbf{r}$.

14. Cystiphyllum vesiculosum, vc.

The Withycombe Corals are of various colours, red, yellow, grey, and black, and are usually more or less impregnated with iron. Red and yellow specimens are the commonest, and the latter generally show the structure best, which is also the case with the Carboniferous Corals of Clifton.

With reference to the shales which occur in the Withycombe Limestone, I may mention that Spirifers are common in the quarry referred to above, and in another, on the left side of the valley which leads from Withycombe to Dumbledear, are to be found examples of Terebratula, Spirifer, joints of Encrinite-stems, and a large species of Cuculloea, but no trace of the Corals of Sandhill Farm. In the Limestone of this quarry there are cavities containing a substance like decomposed manganese.

I also discovered, in a field upon the same farm (Sandhill), a portion of the conglomerate band, which a reference to the Map of the Geological Survey will show to be frequently observable in the New Red Sandstone of the district. It is visible for a few yards as an artificial section of no great depth, below the surface of the ground that has been worked for farm purposes. The conglomerate at this point abounds in Carboniferous Corals, amongst which I have observed Syringopora (ramulosa?), a Zaphrentis, Lithostrotion Martini, and a Cyathophyllum; also other characteristic Mountain Limestone Fossils. It is singular that Devonian and Carboniferous Corals should be found in such close propinquity. Previous to my ascertaining the occurrence of the conglomerate at this spot, I had found a specimen of a Carboniferous Syringopora, in a cart-track, beside some Devonian Corals, and was much puzzled, on learming that it belonged to a distinct formation, how to account for its presence in such a locality; but on the bed being pointed out to me, the mystery was explained.-Yours truly.

Severn Housh, Hhingury, Bristol.

Sphencer Grorge Prerohtal.

THE LOWER NEW RED SANDSTONES OF CENTRAL YORKSHIRE.

To the Editor of the Geocogroal Magazinis.

SrR,-Perhaps the following notes on the so-called Lower New Bed Sandstones, lying between Fountain Abbey and Ripley, may 